\title{
GAMES IN FOREIGN LANGUAGE CLASSROOMS: TAIWANESE STUDENTS' PERSPECTIVE
}

Keywords: game, motivation, vocabulary, Taiwan, foreign language

\begin{abstract}
The study has been designed in order to answer the growing demand for systematic implementation of English language games into FL curriculum at the university level. The purpose of this paper is to analyse how Taiwan-based learners perceive the use of games in the classroom. The qualitative data has been obtained from in-depth interviews with three individuals majoring in EFL and Slavic languages. Among the main benefits of game-supported instruction, students mentioned breaking the routine and raising motivation, along with educational aspects related to introducing, reviewing, and testing the material. They also offered guidance for instructors who plan to deploy games in class. Their overall perception was very positive, which allows the conclusion that it is advisable to introduce games to a wider audience of Taiwanese students. If doing so really can raise motivation to master foreign languages and whether it will translate into measurable progress in Taiwanese students' linguistic advancement is another issue worth future investigation.
\end{abstract}

\section{INTRODUCTION}

The idea of this project emerged as the answer to a growing demand for systematic implementation of English language games into the teaching curriculum at the university level, made by the authorities of the researcher's school. Their efforts remain in accordance with the recommendations of numerous scholars, with D. Persico among them, who claimed that "[p]olicymakers should prioritize awareness raising and training initiatives for players, parents and teachers, should

"natalia.tsai@onet.eu, Hsin Wu University, College of Hospitality and Tourism, The Department of Applied English, No. 101, Sec. 1, Fenliao Rd, New Taipei City, Linkou District 24451, Taiwan. 
actively facilitate GBL (Game-Based Learning) uptake in formal education, and support the development of games of cultural and ethical value" (Persico et al. 2019, p. 1688). Their main goal is to motivate students and promote favorable attitudes towards EFL learning. It is not uncommon for technical college students, especially non-English majors, to lack the skills and strategies necessary to progress (Liao 2004, p. 282). On the other hand, the writer remains deeply concerned with her passion to introduce Taiwanese students to the overseas educators, so that their unique needs are better assessed and catered for (Tsai 2015, 2019, 2020). Before the outbreak of the coronavirus, back in 2016, almost 8 thousand of Taiwanese citizens (7,949, to be precise) obtained student visas to study in the European Union and the top 5 destinations included the United Kingdom (at that time still a part of the E.U.), France, the author's native Poland, Spain, and Germany. ${ }^{1}$ Two years later, in 2019, the number exceeded 9,000. In the same year, there were almost 23 thousand of Taiwanese students in the U.S. alone, contributing 824 million dollars to American economy. ${ }^{2}$

In 2019, there were 152 universities in Taiwan. The total number of students at that time was $1,213,172 .{ }^{3}$ Due to the demographic changes, though, each year these numbers decrease, which influences the dynamics of the academic life and the school policies. As of May 21, 2021, the total population is $23,854,900^{4}$ and it starts to show a slight increase comparing to the previous two years. However, universities still need to deal with a low wave of candidates born at the beginning of the 21 st century and some of them have already been closed. ${ }^{5}$ Thus, the unstinting, all-out efforts to attract the new students and to guarantee the considerable satisfaction level. This is one of the reasons why students are asked to make an appraisal of teacher's performance in each of the classes. In some universities, this evaluation is taken very seriously. It is also recommendable to spice up the on-line syllabus by adding a few special tasks, which will offer a fair chance to attract more participants. Another feature worth mentioning at this point is that Taiwanese education, from the elementary to the tertiary level, is extremely test-oriented. However, oftentimes the test takers do not know how to study and what it means, for instance, to really learn a word.

In prestigious universities, where the decreasing birth rate does not pose such a big problem, candidates still undergo strict recruitment procedures. In one class, you will work with a group of high-achievers, carefully selected from the whole Taiwan. But there is more to the story. In many schools, the reality

\footnotetext{
${ }^{1}$ https://www.ecct.com.tw/inc/uploads/2018/02/2017_eu_taiwan_factfile_1.pdf (accessed on: 03.08.2021).

${ }^{2} \mathrm{https}: / /$ www.export.gov/apex/article2?id=Taiwan-Education (accessed on: 03.08.2021).

${ }^{3}$ The latest data available at the government site: www.taiwan.gov.tw, www.english.moe.gov.tw (accessed on: 03.08.2021).

${ }^{4} \mathrm{https}$ ://www.worldometers.info/world-population/taiwan-population (accessed on: 03.08.2021).

${ }^{5} \mathrm{https}: / /$ www.ceicdata.com/en/taiwan/education-statistics/number-of-school-college (accessed on: 03.08.2021).
} 
looks strikingly different. One of the defining characteristics of that environment might be a diversified proficiency level within one class. Students demonstrating higher fluency in English would study along with peers unable (or unwilling) to make a sentence. Motivation to study is another issue. In many cases, it is just not there. Many young individuals lack discipline and display symptoms of serious addiction to social media and video games. Your job, both literally and metaphorically, is to engage those students and win them back, putting them on the right track. Here is where the school authorities hope to see the game at work.

One more note to get a clearer picture of the situation. In many classes, there are students with documented special needs. Additionally, from the researcher's own observation, there are even more kids with no official diagnosis of their syndromes, often due to the widespread social stigma attached to their impairment. You have to try to open them up. You have to bring them in.

So, this paper serves as the very first step in the researcher's effort to make different elements of the teaching game play well together, so that they harmonize and lead to the best possible educational results. Unlike in many other studies that focus primarily on English instruction, the author turned to multilingual individuals with a wider learning experience. The long-term goal is to carefully identify a happy medium, so that those who want to learn, can do so in even a better atmosphere, those who do not want to learn, can change their mind without even knowing when, and, finally, those who design the curricula and conduct the sessions can yield excellent results. Understanding the needs of all of the stakeholders is indispensable to achieving this goal. The researcher herself has never been particularly enthusiastic about language games at the academic level. Could they add the element of playfulness and relieve the perceived pressure without sacrificing the quality of teaching? How much of the teaching time should they occupy? How to manage the class so that students do not lose a focus and remember to be responsible for their own progress, without blaming the teacher for not providing sufficient (from their point of view) entertainment? Finally, are not young adults supposed to grow mature, so that they can soon get into and survive in a demanding reality of a workplace? Is it not going to postpone this progress if we lure them that success comes with little or no effort? In the hope to find some of the answers to the questions posed above, let us now turn to the research in the field of GBL.

\section{LITERATURE REVIEW}

To begin with, it is possible to draw an analogy between games and linguistic practices, which is seen as a reason why they may successfully serve certain pedagogical functions (Edwards 2019, p. 675). As one can easily notice, it is not uncommon among instructors and learners alike to emphasize, or maybe even 
overestimate, the component of playfulness of the approach: "One of the challenges in teaching English as the second language is to make it as effortless as possible" (Fernandez 2009, p. 4). The gamified curriculum has been proven to provide a framework for a wide range of interventions, from promoting higher participation in class to monitoring students' improvement via self-assessment techniques (Buttner 2007, p. 10). In the hope to investigate the efficiency of game -based instruction, numerous researchers from different academic fields have paid attention to the impact of games on students' motivation and retention (Borit, Stangvaltaite-Mouhat 2020, Jabbar, Felicia 2015, Varela et al. 2014, p. 504). A wealth of projects documented Taiwanese students' vocabulary acquisition through a game-supported instruction, often finding a significant correlation of both (Chen et al. 2019, Chou 2014, see also Wu et al. 2020 for a wider Southeast Asian perspective) or appealing for more support in this matter (Liao 2004, p. 283). Importantly, the results of some studies disproved the hypothesis regarding a positive relationship between the experienced enjoyment and learning outcomes and showed no direct link between fun and learning (Iten, Petko 2016, p. 161). From that point of view, it might be, thus, safer to perceive the implementation of such activities as a way of enriching students' experience, but not necessarily the main instruction tool. Their perspective remains in opposition to the proponents of more gamified approach, with Wright among them, when he claims that "[i]f it is accepted that games can provide intense and meaningful practice of language, then they must be regarded as central to a language teacher's repertoire and not merely a way of passing the time" (Wright 2006, p. 2).

Some scholars explored the social dimension of games and examined to what degree they enhanced the inclusion of students with disabilities (Dillenburger, Coyle 2019). Barron (2006, p. 6), who analyzed various forms of technology-supported fluency building experiences, claimed that playing games with peers translated into higher accumulation of expertise in teenagers while promoting the construction of one's identity, a sense of belonging, a sense of competence, the development of interests, and the interest in joining extracurricular activities.

A great deal of merits has been abstracted by the enthusiasts of the game -based approach to teaching. Here are just a few of the examples: eliminating boredom; making learning more enjoyable; experimenting with different rules and roles; triggering motivation; promoting self-confidence, engagement, persistence, and focus; activating social and problem-solving skills; and increasing the rate of academic success, to name just a few (Cardenas-Moncada et. al. 2021, p. 71, Frydrychova Klimova 2015, p. 1158, Siek-Piskozub 2011, p. 283, Sikorska 2017, p. 97). Wright (2006, p. 2) emphasized that games provide a meaningful context in which one can experience the language, rather than merely study it. Besides, he noted that they often involve repeated use of the same words or 
structures, not unlike in drills. The difference between the two is that in a game, emotions come to play as well. The same author offered a wide range of ready-to-use solutions for students with varying learning styles, that is for visual, auditory, and kinesthetic learners.

There are many downsides to it as well, as discussed by Persico et al. who identify them as "tensions" (2019, p. 1694). Among their concerns, their informants had mentioned gender inequality, ostracism (as an even tougher form of peer bullying), negative stereotype reinforcement, violence, and overly aggressive competition that would pose a challenge to the class dynamics. The authors warn against overestimation of the motivating potential of gamified instruction and call for investments in the development of games with culture and artistic value (Persico et al. 2019, p. 1712). Their conclusion is as follows:

[i]t appears that bringing games into the formal education sphere is something that can be done and is worth doing, but given the above-mentioned pitfalls, it is far from easy and deserves great caution. For one thing, teachers need to cater for student diversity and respect the free nature of play. This means gaining familiarity with many different kinds of games, adopting suitable selection criteria and knowing how to smoothly integrate gameplay within the limitations posed by school timetabling and organization.

(Persico et al. 2019, p. 1694)

The fundamental assumption underlying GBL is that the inclusion of the teaching/learning content into the gameplay enhances enthusiasm and engagement and leads to better outcomes than its traditional, often implicitly understood as "overly serious" or "boring", counterpart. One may use widely available, off-the -shelf games or the so-called serious games, deliberately designed for education by the learners, teachers, or other professionals and prioritizing the instructional dimension over entertainment, operated with or without technological support (Thorne et al. 2009, p. 808). The latter kind, often referred to as analog games, consists of the following six kinds: dice and luck, outlay games, thinking games, quiz-/communication games, role plays, and, finally, dexterity games (Borit, Stangvaltaite-Mouhat 2020, p. 764, see also Frydrychova Klimova 2015, p. 1158).

The author of this study represents a mildly skeptical stance, which encourages her to collect the first-hand information that would allow her to better understand the stakeholders' perspective on the issue. ${ }^{6}$ Hence, the qualitative results obtained from the in-depth interviews provided some insight into students' perceptions of games and their application in the educational context.

${ }^{6}$ This is the first stage of a bigger project that involves a series of in-depth interviews with the policymakers, instructors, and students. Due to the length limitation, the following report includes only the data obtained from the learners. 


\section{PARTICIPANT CHARACTERISTICS}

The following paragraphs come with a brief introduction of the informants. Student 1 (henceforth, S1) was a male in his mid-twenties, obtaining a C1 certificate of proficiency in Russian (currently, his major) and B2 in English. A beginner in the Polish classes, he also reported having learned Japanese for 1 year. At home, in the southern part of Taiwan, he used Chinese and Taiwanese. With background in finance and business, he later switched to the field of language studies in a top national university, where his performance has been very successful, with the average grade higher than 90 (out of 100). He reported studying by himself for at least 10 hours a day: "It can only be more, but not less", he noted.

Student 2 (S2) was a female in her early twenties, undergraduate in Slavic studies at the same public university as Student 1, fluent both in Russian and English (intermediate - as assessed by the cases and/or confirmed by the certificates held), learning Polish and Spanish (both as a beginner). Her native languages, just like in the case described above, were Chinese and Taiwanese. She came from the same city in the south of Taiwan. Her academic performance was rated as high, beyond 90 . Self-studying took 6 to 8 hours of her weekdays. On weekend, she said, it would be longer.

Student 3 (S3) was 19, male, a freshman (English major) in the undergraduate program in a private technical school. Bilingual from his childhood, of Taiwanese and German descent, the man displayed numerous symptoms of Asperger's Syndrome, but had never been officially diagnosed. He showed serious signs of addiction to video games, an activity that was consuming both most of his attention and time (up to 8 hours a day on the weekday and technically whole weekends and holidays), which significantly impaired his ability to focus on school assignments. Thus, his recently failed four out of ten subjects, receiving grades below the passing threshold (which is 60): The score ranked from 19 to 58. As he often reported, his enthusiasm for studies fizzled up back in the childhood, when he had felt bullied by his peers and faced numerous episodes of domestic violence ending in his parents' difficult divorce. Student 3 describes himself as a lazy person, demonstrating little determination to improve. As a solitary type, he has got not much will to interact with others, seeing peer communication as a violation against his solitude. He described himself as ,a person who doesn't like to talk, a quiet person who doesn't like to work too much." Passive, resigned, and lacking self-discipline, he admitted that, in the context of school, he no longer cared much. His case clearly illustrates how complex the stories may be behind the stereotypical image of a "shy Asian" who avoids open confrontations or standing out. It is also a perfect example of a learner with special needs who remains in education without any official diagnosis of his syndromes. As a result, if the 
teacher has certain standards and requirements that apply to all students, there is no reason to treat such individuals in any special way, which oftentimes leads to a confusion and frustration.

All of the cases came from middle-class families where education was highly regarded by other family members, who themselves held or were currently studying to get university diplomas and were professionally active in their fields. The informants were based in the capital of Taiwan, that is in Taipei City. They were physically healthy. Their participation was voluntary and the informed consent was given. Both Student 1 and Student 2 worked as teaching assistants in education. In opposition to the last case, they demonstrated a considerable level of autonomy and intrinsic motivation in learning: from the point of view of the teacher they were extremely proactive, curious, and very self-disciplined. ${ }^{7}$ Besides, both of them had surprisingly high levels of self-awareness as language learners and Student 1 had been trained as a foreign language teacher himself.

\section{INTERVIEW FINDINGS}

In this section, the main findings of the interviews will be presented. ${ }^{8}$ To begin with, the general perception of games in class was very positive. They were seen as "relaxing" (S1), "interesting and funny" (S2), and "cheering you up" (S3). As we can see, the participants tended to polarize two approaches. Teaching with games was "exciting", as opposed to "only sitting and writing", since "fun is important, the class won't be so boring" (S3).

Importantly, games in university were not necessarily perceived as unsuitable for young adults: "Childish? - Not at all! Actually, many classes are more boring than the games. Games can give us happiness!" (S2). They would add the element of fun and messing around in an otherwise serious class, like playing blind man's bluff or ghost catching (S3). Students would appreciate the teacher's effort to design a game for them, as oftentimes done by their Polish teacher. They enthusiastically reported details of his repertoire, which included deployment of PPT slides, sound tracks, and a wide range of features ranging from advancement levels to time restrictions for participants: "It works! The teacher prepared many

\footnotetext{
${ }^{7}$ In fact, Polish Conversation class conducted by the researcher could be continued thanks to their efforts and persistence to rearrange the school teaching schedule.

${ }^{8}$ Please keep in mind that the following study was designed and carried out right before a rapid outbreak of the coronavirus in Taiwan in May 2021. The collection of data took place when students were still physically present in the classes, having little or no idea that this could change. In fact, the TV news reported a dramatic increase in the number of contracted patients two hours after the last of the interviews was completed. The school's decision to switch to on-line teaching followed soon afterwards, in the same afternoon.
} 
kinds of games by himself, even with sound! We need to spell/pronounce the words, to correct the grammatical mistakes which team is faster to complete. We choose the level" (S2).

Among the main advantages the participants saw a chance to "gain many kinds of stimulation, not only through ears and eyes" (S1), which would bring variety and arouse more interest than a monotonous instruction. As pointed out by the same person, "the instructor needs to have many ways of introducing the material, not only writing on the whiteboard or reading." That is when a game becomes a form of escape from the classroom routine: "I guess it's okay. Switching your teaching style for a while. Always keeping the same way would be boring." (S3). It also helps to consolidate the material and review before a test and to "promote students' interest and self-learning, so that they will study more at home" (S1).

As students are generally "more impressed" by a fancier way of introducing a new content, it "will raise our happiness level and enhance the motivation to study. Because if this class is interesting, I want to study more. If students know there are games, they will want to learn more to get a high score" (S2). In other words, a game in class can contribute to an increased absorption of the input, especially if it evokes positive emotions, raises interest in class, and opens a channel to the learner's mind. Being aware of the possibility of participating in it, students are encouraged to self-study, at least in some cases.

Having fun is one thing, but for some students a game may be a clear indicator that a particular chunk of material later may be tested. They may then gladly connect the content of the game with the exam: "Wow! I know it!" (S1) or get inspired to pay more attention in the future: "Of course, students will be surprised. If it's the same, they will play the game more seriously next time" (S2). It is, however, desirable to give a hint that what is being reviewed in a care-free way should be later consolidated: "You must explain it before the game, so that students know the questions are connected to your teaching. You need a clear message. Most of the students have the stereotype: Game must be fun, relaxing, the opposite of work" (S1). The latter point was clearly expressed by the third participant, who said that including something into a game is not seen as an explicit message to care too much: "Fifty-fifty. If it's important, I will review it. If it's for fun, I won't do it too seriously" (S3).

Noticeably, games in the foreign language learning context may promote one's autonomy by "letting students think by themselves easily, more efficiently than writing down the answer on a paper" (S3).

Asked if games can prepare students for future interactions with people outside of classroom, the informants responded in a rather positive manner. For S1, for example, they were "totally useful in every aspect of communication", as they could include different aspects of language learning, from spelling and pronunciation to culture-related problems. S2 suggested that conversation games would 
be particularly useful, especially when one needs to guess the upcoming lines of a given dialog. They could also prepare the players for the future teamwork, as pointed out by S3, who personally, however, was hoping to avoid this possibility: "Teamwork? It depends on what type of person you are. Would you rather work with others or just by yourself? It would help a bit", he said, but not without reservations. For him, it was a potentially stressful situation and, in order to avoid anxiety and tensions, he personally preferred to work by himself: „I don't like to work in a team. In a team, you need to discuss things with your partner, you may have issues, different minds, get into a fight."

As such, games are a helpful ice-breaker, especially at the beginning of a term, because, as S2 put it, ,sometimes you don't know anyone in the class, so if you play, you get to know them better." She also expressed her preference for games based on group assignments, rather than individual work. According to $\mathrm{S} 1$, both forms of a play were equally desirable, just from the teacher's point of view, he noted, it might be easier to prepare a game for teams than for all individuals separately and it could affect the way one should manage the whole activity: "Both are great. Playing in teams makes it easier to control the class. Individuals? It takes more time to prepare." He also suggested that it is beneficial to have students circulate between different teams, so that, as a result, they learn how to collaborate with classmates outside of their closest circle: "Every time you must change the members of the team. They will know how to create team work with different people."9

One may wonder how to carry out such activities in a language lab and what to keep in mind to provide a high-quality teaching. Here is a list of hints given by the students.

Limited time: The pressure to provide the answer as soon as possible is a good stimulant. There is that portion of "stress to answer quickly, finish on time", as "the controlling time is one of the most important things in the game" (S1).

Varying levels: Students excitedly reported that their teacher allowed them to choose the degree of difficulty, which, in turn, translated into the grades they could earn: "Easiest level - less points. Difficult one - more" (S2). The teacher would then have a detailed record of their score. It is also critically important to make sure that the activity matches the current degree of advancement, which may be different, depending on the individual: "Any level, but games need to be designed accordingly" (S1). Besides, each participant can learn something else from the same exercise, as suggested by S2, who said: "Students have different levels, so the abilities they gain from the games are different."

${ }^{9}$ His view is in accordance with the policy adopted by Taiwanese schools, where students, from the earliest stages of education, might be assigned to different classes and tutors every second year. Besides, teachers require them to form teams. Individual work is not given as much approval as it is in the Western educational context. As a result, young people are used to cooperate with different persons in varying circumstances. 
The preferred frequency of games in class varies: "Four times per semester" - suggested S1, adding that he would be glad to see the activities evenly distributed, preferably once a month. He believed that games needed to be carefully incorporated in the overall teaching plan without dominating it: "The process of the class needs to go in first. In the beginning, we need to learn something, not to play the game and start the class. It's good for students, but the teacher must recreate the teaching plan or the time will be limited and the schedule gets messed up." Student 2 was willing to see the games even more often, depending on how much time they would take: "If it's a small game, we can play more often, maybe 3-4 times in half of the semester. But if it lasts only less than 10 minutes, then we can play even more, up to 10-15 times!" The third participant left it up to the instructor. He, however, seemed to be more resigned than passionate: "If the teachers want it, then it's okay. Before, I was nervous, unhappy about the way they teach, but now I don't care", he reported.

Emphasizing games in the syllabus was another step suggested by $\mathrm{S} 1$ and S2. The former one expressed it this way: "It is also important to write it in the syllabus. If your class is interesting, students will give you higher feedback on the platform." The latter informant agreed, adding that she would always carefully study the instructor's syllabus before signing up for a class: "I always read a teacher's syllabus. If I see it's interesting and fun, I will take that course," she said. Put briefly, including games in your on-line teaching plan attracts more students, which is important if there is a minimum number of the participants that allows the department to open that particular course. Second, if done skillfully, it will result in more favorable evaluation grades for the instructor.

Rewarding the participants is another issue that emerged during our conversations. As it turned out, there are many variations here: You can offer tasty treats to encourage higher engagement: "You can design the game that everyone can get some treats," said S1, but S2 saw a limitation to the indulging approach: It might occur pricey and the people will get spoiled. In her words, "Some students will like it, but not all. Snacks are good sometimes, but not every single time. If you have many students in class, it costs a lot of money. If you offer treats too often, students will get used to it, so if once you don't have, they may feel surprised, like "Why no snacks today?" Besides, S1 suggested giving points for one's performance in games and including them to the final score: "The results can be calculated as a part of our overall grade, which is better than presents or candies. It's useful both for the students and the school." Another idea he had was that the players could receive points no matter how well they did, which would boost their motivation to study hard and join the next in-class competition: "The same point for the losers and winners, it's just about the participation, so that nobody feels discouraged. Maybe double score for working hard. Satisfaction is enough to give the kick to study." S3 offered 
a very sane and practical insight, pointing out the importance of the emotional aspect: "Rewards? It's not so important. Snacks? It's okay, just when you eat it, then it's gone. Satisfaction? Yes, I will be satisfied: I just finished the game successfully and learned new skills and information." He expressed his conviction that games, unless designed specifically for testing were for fun and not for the points: „If it's a test, then you should give a score. When it's not, then it's just for fun. Games are for fun. Grades are not important. Grades can't tell how good the person is in the real life." From his last statement we can also deduce that a game might provide an opportunity to better know the classmates. It could potentially reveal some of the personality traits that otherwise remained hidden. That is another, social, dimension of the activity.

Including body movement into a game was another aspect mentioned by the informants. This, however, should be done with caution: "Your game is very good if it involves some movement, but not too much. That would be weird," said S1. "In our methodology class (Teaching Chinese as a Foreign Language), the teacher demonstrated some games and gestures to introduce several Spanish verbs, like to read or to fly. I remember it till now", he added. S2 noted that hands-on approach to teaching can exhilarate and enliven an otherwise lame atmosphere in class and enhance the chances of successful acquisition: "Our bodies memorize more. Many students can concentrate in class only 20-25 minutes. Sitting is boring. In lots of classes, we just sit and do nothing." As already noted above, the third participant suggested relaxing and funny games that included movement and fooling around, which brings us to the next notion, that is to a joyful play.

Element of fun was seen as an inseparable part of the game and a remedy for boredom in class, when students "kind of sit there and listen to what teachers say and everyday it's the same" (S3). (This was not necessarily bad, for that particular informant actually enjoyed the predictability the routine offered.) Here is a rather explicit comment offered by S1, "Fun: Atmosphere that makes the class alive, because if the program is very boring, the class will be dead. If the topic is dull and the students are sleeping, let's say for 40-45 minutes, but the teacher plays the games related to the topic for at least 10 minutes, then it's fine."

Among other essential functions that games can fulfil in a language lab, the following were mentioned: introduction, consolidation, and, finally, testing. Firstly, S3 suggested that playing a game can become a good occasion to introduce new, practical skills or information that went beyond the theory: "some important stuff useful in life, extra information." When asked to provide some details, he explained that games might become a training ground for eventual encounters in the target language. They could, for instance, show how to successfully use the language to avoid being tricked: ,how to defend yourself, react to strange calls on 
the phone, recognize it, when someone wants to cheat you for money." ${ }^{10}$ It is also, as explained by the same informant, a good way to process and consolidate the new material („,kind of special way to help students to remember stuff”). At the same time, this participant would not expect to learn too much, „because it's just a game, and games don't teach information," he replied. When asked to assess what language skills could be improved via games, two of the informants agreed that it was useful for promoting the four abilities, i.e. listening, speaking, reading, and writing. The ability to train the latter one was questioned by S3. Reviewing material in the form of a game can activate students and engender their enthusiasm for learning: "When you can review something and improve the motivation, to accelerate the student's brain. If not, students will lack motivation," as pointed out by S2. When it comes to testing, students offered the following remarks. First, this technique could be more useful in smaller groups and for less important tests, so that there would be no room for any dishonest practices: "In a small group it's okay. Cheating will be eliminated" (S1). "For a small test it's fine, but not for a bigger one, because students will cheat. Nowadays it's easy to cheat via the Internet" (S2). For S3, checking one's knowledge this way had a clear advantage, as it actually stimulated the cognitive processes: "Of course, it might help. Make students more excited and make them think more. Regular tests are boring, just sitting and writing."

Finally, let us briefly consider what potential shortcomings of games were discussed by the students. In other words, what should we avoid when designing a game? From the point of view of S1, the activities need to be well-designed and adjusted to the number of participants. "Some teachers will design the game very quickly, so it keeps repeating. The first three, four people have fun, but the rest will feel it's boring," he warned. So, the instructor needs to give it a thought and take the game seriously. The same informant expressed his conviction that a game needs proper saturation. In other words, it has to be rich and attractive enough in terms of the content and technique. Another problem was the level of challenge posed: "if too easy or too difficult" (S2). Boredom was to be avoided as well. S3 advised the instructor not to follow the rules too strictly. Finally, S2 mentioned that there might be some technical constraints, like the one described here: "If we need to type something, it will lower our speed. We didn't type in the Cyrillic alphabet too fast, so we failed the test. But just to click or press is totally fine."

${ }^{10}$ In Taiwan, this skill might have certain degree of real-life application, for it is not uncommon for people to receive phone calls from numerous well-trained con artists, many of whom are based in the neighboring countries. They are not very likely to approach you in English, but they may pose a real danger to one's bank account and, as such, catch a young person's imagination. 


\section{DISCUSSION AND CONCLUSIONS:}

Generally speaking, the analysis of the data revealed a very enlightened attitude towards games in foreign language classes. They were seen as a remedy against the routine, with agreement with authors who, like Fernandez (2009) saw a need to exhilarate the students a little bit. The interviewees thought this was a good way to bring some variety to the instruction, far too often perceived as monotonous. They saw obvious educational values in it, a way of introducing, reinforcing, or even testing the new material, in accordance with some studies recalled earlier in this paper (Borit, Stangvaltaite-Mouhat 2020; Jabbar, Felicia 2015). What is more, the interpersonal dimension was discerned: Games were seen as social lubricants promoting students' cooperation skills, as long as they were willing to work with others (Cardenas-Mocada et. al. 2021, p. 71).

What does it mean in practice? First, a game may be welcome by students and, if skillfully designed, properly adjusted and carried out, has a potential to attract students' interest. Individual preferences vary, so it is impossible to design a one-fit-all activity. Thus, each time the task can be different to appeal to different players. If this in the long term translates into better learning outcomes, as questioned by Iten and Petko (2016), is another issue beyond the scope of this paper. They may serve a great variety of purposes, depending on the actual needs, and add up to the instructor popularity. Probably, as such, they are likely to create a better image of a particular learning environment, which is of critical importance to the schools struggling with the recruitment and retention crisis.

The starting point of the initiative was to find a remedy for the overwhelming disengagement observable in some FL classes. However, the lack of motivation does not necessarily stem from the poor classroom management or the lack of fun. Thus, the need arises for further, more detailed study and the openness for a real dialog, however uncomfortable the outcomes may turn out. Another issue is the escapist tendency to eliminate seriousness from class, with GBL perceived as a way to ensure just that, as we can see in the following quote: "With the popularization of the game, the element of seriousness in knowledge acquisition has been consciously weakened, and vocabulary memorization is no longer boring" (Wu et al. 2020, p. 93). Why are educators so afraid of being serious? What are they trying to protect students from? Is it a way in which some decision makers are trying to compensate for the overly test-oriented teaching?

Another feature of play is competition. Here, again, some authors propose softening of the approach and eliminating this element, so that the triumph can be celebrated by all: „The problem [italics - N.T.] with some games is that they tend to make one person the winner and the rest losers. What we need in the classroom is for everyone to experience success as much as possible. Look for games or 
ways of playing games which allow just that" (Wright 2006, p. 9). Undoubtedly, in some particular cases, especially in slower or impaired students, it could be helpful, but probably an overly mild style does not need to become a standard. Could games help us serve the opposite purpose, that is the one of preparing students for the toughness of life? Hopefully, one day they will experience their victories, but, unavoidably, sometimes they will fail. If done tactfully, broadening this awareness would be a long-term blessing. And, by the way, would such "decaffeinated" games still raise that much interest?

One may wonder how to approach autistic individuals like Student 3: passive, subdued, and vulnerable. Given a poor attitude and learning outcomes, would not a game be just another excuse for procrastination? How to arrange the activity to bring him in?

These are just some of the aspects of game-supported teaching. The responses came from three individuals. If a golden mean should be found and customized to this specific educational culture, there is an urgent need to allow more stakeholders to voice their opinions. This paper aimed to understand the ways in which students from two different educational backgrounds react to the idea and it proved that there is a room for such kind of intervention in FL classes. Another intention was to shed light on the local teaching/learning context and it can be assumed that now overseas Readers can have a clearer picture of the situation.

\section{REFERENCES}

Barron B., 2006, Learning Ecologies for Technical Fluency: Gender and Experience Differences, "Journal of Educational Computing Research", 31 (1), pp. 1-36, doi:10.2190/1N20-VV12-4RB5-33VA

Borit M., Stangvaltaite-Mouhat L., 2020, Go Dental! Enhancing flipped classroom experience with game-based learning, "European Journal of Dental Education”, 24, pp. 763-772, https://doi. org/10.1111/eje.12566

Buttner A., 2007, Activities, Games, and Assessment Strategies for Foreign Language Classroom, Eye on Education, Larchmont, NY.

Cardenas-Moncada C. et al., 2021, Game-Based Student Response Systems: The Impact of Kahoot in a Chilean Vocational Higher Education EFL Classroom, "CALL-EJ", 21 (1), pp. 64-78.

Chen, C. M. et al., 2019, Effects of a mobile game-based English vocabulary learning app on learners' perceptions and learning performance: A case study of Taiwanese EFL learners, "ReCALL", Volume 31, Issue 2 , May 2019 , pp. 170 - 188, doi: 10.1017/S0958344018000228

Chou, M.H., 2014, Assessing English vocabulary and enhancing young English as a Foreign Language (EFL) learners'motivation through games, songs, and stories, "Education", 42 (3), May 2014, pp. 284-297, doi:10.1080/03004279.2012.680899

Dillenburger K., Coyle C., 2019, Education for all: The Good Inclusion Game, Behavioral Interventions, 34, pp. 338-351, doi: 10.1002/bin.1671 
Edwards G., 2019, Language Games in the Ivory Tower: Comparing the „Philosophical Investigations" with Hermann Hesse's ,, The Glass Bead Game", "Journal of Philosophy of Education”, Vol. 53, No. 4, pp. 669-687.

Fernandez G., 2009, Games for ESL Students, Lulu Press,

Frydrychova Klimova B., 2015, Games in Teaching of English, Elsevier, Precedia, "Social and Behavioral Sciences", 191 (2015), pp. 1157-1160, doi: 10.1016/j.sbspro.2015.04.312

Jabbar A. I., Felicia P., 2015, Gameplay Engagement and Learning in Game-Based Learning: A Systematic Review, Vol. 85, issue 4, pp. 740-779 https://doi.org/10.3102/0034654315577210

Liao Y. F., 2004, A survey study of Taiwan EFL freshmen's vocabulary learning strategies, "Journal of Pingtung Teachers College", 21, pp. 271-288.

Persico D. et al., 2019, Meeting players where they are: Digital games and learning ecologies, British Journal of Educational Technology, Vol. 50, No. 4, pp. 1687-1712, doi: 10.1111/ bjet. 12777

Siek-Piskozub T., 2011, Games and plays in foreign language teaching, Band 1, J. Darski, Z. Vetulani (eds), Max Niemeyer Verlag, Berlin, New York, pp. 283-290, doi. org./10.1515/9783111353234.283

Sikorska L., 2017, Gry i zabawy w nauczaniu obcokrajowców polskiej grzeczności językowej, “Języki Obce w Szkole", 3, pp. 97-101.

Thorne S. et al., 2009, Second Language Use, Socialization, and Learning in Internet Interest Communities and Online Gaming, "The Modern Language Journal", 93, Focus Issue, 0026$7902 / 09 / 802-821$

Tsai N., 2015, Taiwanese English learners' perceptions of errors in speaking, “Acta Universitatis. Lodziensis Kształcenie Polonistyczne Cudzoziemców” 22, 10.18778/0860-6587.22.08

Tsai N., 2019, Social media in foreign language teaching and learning - a review, "Acta Universitatis. Lodziensis Kształcenie Polonistyczne Cudzoziemców”, 26(26), pp. 149-159, doi:10.18778/0860-6587.26.09

Tsai N., 2020, Polish - just like "another English": Perceptions of translanguaging and other bilingual practices in English and Polish FL classrooms in Taiwanese universities, "Acta Universitatis Lodziensis. Kształcenie Polonistyczne Cudzoziemców”, Vol. 27, pp. 367-387, doi: $10.18778 / 0860-6587.27 .21$

Varela A.B. et al., 2014, Video Games in Educational Settings: Developing Skills for New Media Learning, in: M. Angelides, H. Agius (eds), Handbook of Digital Games, First Edition, The Institute of Electrical and Electronics Engineers, Inc., John Wiley \& Sons, Inc., pp. 502-522.

Wright A., 2006, Games for Language Learning, Cambridge University Press.

Wu. Q. et al., 2020, The Effect of English Vocabulary Learning with Digital Games and its Influencing Factors based on the Meta-Analysis of 2,160 Test Samples, "iJET", Vol. 15, No. 17, pp. $85-100$.

https://www.ceicdata.com/en/taiwan/education-statistics/number-of-school-college (accessed on: 03.08.2021).

https://www.ecct.com.tw/inc/uploads/2018/02/2017_eu_taiwan_factfile_1.pdf (accessed on: 03.08.2021).

https://www.export.gov/apex/article2?id=Taiwan-Education (accessed on: 03.08.2021).

https://www.worldometers.info/world-population/taiwan-population (accessed on: 03.08.2021).

www.english.moe.gov.tw (accessed on: 03.08.2021).

www.taiwan.gov.tw (accessed on: 03.08.2021). 


\section{Natalia Tsai}

\section{GRY NA ZAJECIACH JĘZYKOWYCH Z PUNKTU WIDZENIA TAJWAŃSKICH STUDENTÓW}

Słowa kluczowe: gra, motywacja, słownictwo, Tajwan, język obcy

Streszczenie. Badanie opisane w niniejszym artykule przeprowadzono w odpowiedzi na rosnące zapotrzebowanie na wdrażanie różnorakich gier językowych do programów nauczania języków obcych na tajwańskich uczelniach. Poznanie opinii miejscowych studentów na ten temat stanowiło główny cel przyświecający autorce. Dane jakościowe pozyskane zostały poprzez przeprowadzenie wywiadów z trzema osobami specjalizującymi się w językach obcych (w tym wypadku było to dwoje studentów slawistyki oraz jeden student anglistyki). Wśród zalet omawianego tutaj podejścia informatorzy mieli na uwadze przede wszystkim możliwość urozmaicenia zajęć poprzez przełamanie rutyny wraz z podniesieniem poziomu motywacji uczących się. Ich wypowiedzi dotyczyły ponadto sposobów wykorzystania gier w procesie wprowadzania, utrwalania oraz testowania wiadomości. Udzielili oni także wskazówek dla nauczycieli rozważających korzystanie z tej metody. Ogólnie rzecz ujmując, pomysł wykorzystania gier na zajęciach językowych przyjęty został przychylnie, co pozwala wierzyć, że szersze stosowanie tego typu technik w pracy z Tajwańczykami spotka się z życzliwością. Na ile rzeczywiście będzie to miało przeniesienie na poziom motywacji szerszych grup studentów oraz czy faktycznie przełoży się to na postępy w nauce to już zagadnienia na osobne badania, wykraczające poza zakres tego artykułu. 